\title{
Competence development - a key concept of higher education
}

Comments on the article by Susanne Weber and Sabine Funke «An 'instructional' perspective on entrepreneurship education:

focusing on the development of team competencies»

\author{
Kristina Reiss
}

Technische Universität München *

\begin{abstract}
Entrepreneurship education has met new challenges in the last few years. Several studies show that successful entrepreneurs are important for economical growth. However, there is evidence that university education does not always fulfill the goal of adequately preparing young people for this task. Competence development rather than a mere acquisition of knowledge and skills has been identified as an important key concept. This is the starting point for a study performed by Weber and Funke. They discuss how entrepreneurship education programs meet (or do not meet) this task and present an alternative approach for entrepreneurship education. In this comment, the approach is integrated in current views on a competence-oriented education and discussed with respect to its innovative potential.
\end{abstract}

\section{The challenge of university education: supporting competence development}

Education is changing its focus. In particular during the last decade, a shift from input-oriented teaching and learning to a more outcome-oriented education has been initiated in several countries and for many subject matters or domains. Students are asked to develop their competences rather than just spend their time with knowledge acquisition. Accordingly, competence has become a key concept in education. Weinert (2001) defines competences as individual cognitive abilities and skills, which enable a subject to solve particular problems. Moreover, competences encompass the motivational, volitional, and social readiness and capacity to utilize solutions successfully and responsibly. Competence thus reaches beyond knowledge and skills and may be regarded as a component of active and creative problem solving.

In school classrooms, the standards movements in many countries had particularly brought to teachers' minds that instruction should enhance students' competences (e.g. National Council of Teachers of Mathematics, 2000; Kultusministerkon-

* Kristina Reiss, Heinz Nixdorf-Chair Mathematics Education, TUM School of Education, Technische Universität München, Germany; kristina.reiss@tum.de 
ferenz, 2003). Defining standards included new curricular approaches and thus effectively influenced teaching and learning. There was no similar movement at the university level though important reforms took place. During the last few years, the structure of university education in Germany (and other European countries) switched from a diploma to a bachelor/master system, but these structural alignments were hardly combined with content-oriented changes. This general statement applies to the specific subject of entrepreneurship education. Weber and Funke argue that this cannot be seen as coincidental. They provide evidence that entrepreneurship education is not sufficiently based on scientific knowledge of teaching and learning, that it lacks precise curricular goals, and that it can be regarded with respect to its specific subject matter education.

The demands on entrepreneurship education are obvious but difficult to implement in a university curriculum: University education has to convey knowledge of demanding concepts and procedures, must mediate between theory and application, and should prepare for a multi-faceted professional career. Thus, university education cannot restrict itself to students' knowledge acquisition but must aim at communicating entrepreneurial competences.

\section{Business plan and problem solving: between theoretical prerequisites and the demands of practical work}

Research suggests that students need to be actively involved in their learning processes in order to acquire more than tacit knowledge (Gruber, Mandl, \& Renkl, 2000). In order to accomplish this goal, working with authentic problems is suggested. Problems are regarded to be tasks for an individual, which he or she cannot solve by straightforward means (Schoenfeld, 1985). Solving a problem presupposes an active engagement of the student and a profound conceptualization of the components. Problems are regarded to be particularly helpful if they reflect an authentic and realistic context. Applying knowledge and skills in such an environment may, for example, show that theoretical considerations are useful and beneficial in different situations.

Problem-based learning in an authentic context was chosen by Weber and Funke as their initial approach to students' competence acquisition. Moreover, their implementation suggested teamwork between students and (active) entrepreneurs as a most important feature. The precise task was to compose a business plan for an enterprise. Business plan work as defined in this article can be regarded as a complex problem-solving task. Thus, students were presented with an integrated concept. The learning environment included self-regulated learning and continuous assistance, offered individual as well as collaborative opportunities to learn, supported different types of teaching and learning, and also encompassed blended learning.

It is noteworthy, that working in an authentic context can be identified in a twofold manner in this work. On the one hand, the problems presented are authentic and provided by real enterprises. Thus, theory and practice are in a consistent interplay 
with each other in order to find the best solutions for the problem. On the other hand, students are solving the problems in teams, which have to self-organize their work. With respect to the future work of an entrepreneur, this is an authentic situation to which students should be prepared during their studies. Unfortunately, university education still makes intensive use of teaching methods that address large groups of students at the same time. Active participation is hardly encouraged due to a huge number of students. However, we know that successful learning builds up on an active participation of students. Their involvement in an instructional context facilitates competence acquisition.

Weber and Funke implement general paradigms of teaching and learning into entrepreneurship education. They consider recent research in this area and convey results to their specific context and subject matter. This work highlights the importance of a subject matter education, which is embedded in the general educational science as an integral part of this science.

\section{Discussion}

The evaluation of the study shows encouraging results. Students were able to enhance their knowledge and skills significantly. In particular, the experimental group showed better scores for teamwork than the control group. So «teaching counts» is an important message we get from this study. It is not the only message, and, in my view, it is probably not the most important message.

Teaching at the school or the university level is a challenging task, which presupposes subject-matter knowledge, pedagogical content knowledge, and pedagogical knowledge (Shulman, 1986). Obviously, there is no teaching without content and no scientific discipline without a profound content-oriented knowledge base. However, knowing facts and procedures or teaching a subject are fully different aspects within a discipline. Teaching can be founded on general pedagogical ideas, but the specific content will always play an important role.

There are scientific disciplines with a well-established subject matter education like mathematics, physics, or chemistry (and others). It seems that being well-established as a specific subject matter education is linked to the importance of the subject in a school context. If a scientific discipline is taught at school it is generally accepted that its concepts and methods have to be presented in a way that children understand and which supports their view on the subject. Accordingly, there is profound research which takes the subject matter as well the needs of the learners into account. However, this research is mostly restricted to the school context.

Subject matter education at the university level is rare and can be seen as an evolving field. This is particularly true for more or less young disciplines, which do not have school instruction counterparts. Entrepreneurship education must be seen as a new discipline in this respect. The work by Weber and Funke provides (more) evidence that it is a challenging task to establish standards for teaching and learning in this field. Moreover, their work shows how an access to this task is possible. 


\section{References}

Weinert, F. E. (2001). Vergleichende Leistungsmessung in Schulen - eine umstrittene Selbstverständlichkeit. In: F. Weinert (Hrsg.): Leistungsmessungen in Schulen. Weinheim: Beltz

Kultusministerkonferenz (2003). Bildungsstandards im Fach Mathematik für den mittleren Schulabschluss. Bonn: KMK

Gruber, H.; Mandl, H. \& Renkl, A. (2000). Was lernen wir in Schule und Hochschule: Träges Wissen? In: H. Mandl \& J. Gerstenmaier (Hrsg.): Die Kluft zwischen Wissen und Handeln. Empirische und theoretische Lösungsansätze. Göttingen: Hogrefe

National Council of Teachers of Mathematics (2000). Principles and standards for school mathematics. Reston VA: NCTM

Schoenfeld, A. H. (1985). Mathematical problem solving. Orlando FL: Academic Press 